\title{
The bidirectional effects of scorpion's toxins and sodium channels in convulsant
}

\author{
Ying Wang ${ }^{1,3 *}$, Xuhao Wen ${ }^{1 *}$, Defang Chen ${ }^{2}$ and Bin Wang ${ }^{1 *}$ \\ ${ }^{1}$ Liaoning Provincial Key Laboratory of Cerebral Diseases, Department of Physiology, Dalian Medical University, Dalian, Liaoning, China \\ ${ }^{2}$ Technology Centre of Target-based Nature Products for Prevention and Treatment of Ageing-related Neurodegeneration, Dalian Medical University, Dalian, \\ Liaoning, China \\ ${ }^{3}$ Department of Cardiology, Institute of Heart and Vessel Diseases of Dalian Medical University, the Second Affiliated Hospital of Dalian Medical University, \\ Dalian, Liaoning, China \\ \#These authors contribute equally to the work
}

\begin{abstract}
Nowadays, there is a tremendous scope for development of safe and effective drug for the management of epilepsy with decreased adverse effects. Scorpion has been used to treat epilepsy for several of years, while symptomatic acute epileptic seizures may occur in up to $5 \%$ of individuals, especially children, with scorpion stings. $\mathrm{Na}_{\mathrm{v}} \mathrm{s}$ are composed of a pore-forming $\alpha$ and auxiliary $\beta$ subunits, and scorpion venom are classified into $\alpha$ and $\beta$ which both can active on $\mathrm{Na}$ s. Herein, we briefly describe the roles of scorpion's toxins and its bidirectional effects to the pathogenetic mechanism and therapeutic target of epilepsy.
\end{abstract}

\section{Introduction}

Epilepsy is a serious and chronic neurological disorder that affects no fewer than 50 million population globally [1]. The highest risk of epilepsy is in the neonatal period [2], while the highest incidence is in the elderly population across the lifespan [3]. Although great advances have been made in the development of new antiepileptic drugs, like vigabatrin, levetiracetam, topiramate, lamotrigine, zonisamide, lacosamide, rufinamide and stiripentol have been developed for epilepsy treatment [4]. However, seizures in $20-30 \%$ of patients remain refractory to therapies using conventional antiepileptic drugs [5], and all the currently available synthetic anticonvulsant drugs are prone to cause one or more side/adverse effects such as neurotoxicity, dizziness, impaired concentration and cognition function, mental slowing, ataxia, mental confusion, sleep disturbance, anorexia, somnolence, aggression and so on [6]. Therefore, there is a tremendous scope for development of safe and effective drug for the management of epilepsy with decreased adverse effects.

In the past few years, hundreds of polypeptide toxins with multipharmacological effects have been purified from the venom of scorpions, spiders, and wasps, and the scorpion's venom are most widely studied [7]. Some of these polypeptides have either convulsant or anticonvulsant activity and the latter have been considered to be potential candidates for antiepileptic drugs [8]. On the one hand, scorpion has been used to treat various neurological disorder symptoms for over two thousand years and it is the foremost choice for epileptic treatment as a traditional Chinese medicine [9]. On the other hand, symptomatic acute epileptic seizures may occur in up to $5 \%$ of individuals, especially children, with scorpion stings. Hence, a comprehensive description of scorpion's toxins and its bidirectional effects to the pathogenetic mechanism and therapeutic target of epilepsy has the potential and profound impetus function.
Voltage-gated sodium channels $\left(\mathrm{Na}_{\mathrm{v}} \mathrm{s}\right)$ are crucial components in neurotransmission, which are responsible for the generation and propagation of action potentials (AP) along neurons [10]. Based on the opening in response to membrane depolarization $\mathrm{Na}_{\mathrm{v}} \mathrm{s}$ allow sodium entry and thus the continuation of depolarization along the plasma membrane[11]. $\mathrm{Na}_{\mathrm{v}} \mathrm{s}$ are composed of a pore-forming $\alpha$ and auxiliary $\beta$ subunits, the pore forming a subunit is a single-polypeptide chain which consists of DI-DIV structural domains, each domain has a voltage-sensing domain (VSD; S1-S4 segments) and a pore-forming domain (S5-S6 segments). The related research suggested that DIIII VSDs govern the pore opening of the $\mathrm{Na}_{\mathrm{v}} \mathrm{s}$, whereas the DIV VSD controls its fast inactivation [11-14]. Scorpion venom is one of these toxins or (and) drugs active on $\mathrm{Na}_{\mathrm{v}} \mathrm{s}$, is formed by cysteine-stabilized $\alpha$-helix and $\beta$-sheet (CS $\alpha \beta)$ fold cross-linked by four disulfied bridges [15], and the scorpion toxins are classified into two distinct type ( $\alpha$ and $\beta$, both are gating modifier toxins) based on the pharmacological effects and channel binding properties [16,17]. Alpha-scorpion toxins mainly bind to the loop connecting S3 and S4 in $\mathrm{Na}_{\mathrm{v}}$ domain IV and inhibit the fast inactivation of $\mathrm{Na}_{\mathrm{v}}$ channels without dramatically affecting activation of the channels [18-24]. Beta-scorpion toxins mainly binds to the Domain II VSD and holds that VSD in the activated state and increase $\mathrm{Na}^{+}$currents by shifting the threshold of $\mathrm{Na}_{\mathrm{v}}$ activation in the hyperpolarized direction by more than $20 \mathrm{mV}$ [25-29].

${ }^{\star}$ Correspondence to: Bin Wang, Technology Centre of Target-based Nature Products for Prevention and Treatment of Ageing-related Neurodegeneration, Dalian Medical University, Dalian, Liaoning, China, E-mail: wb101900@163.com

Key words: epilepsy, scorpion venom, voltage-gated sodium channels (Navs)

Received: November 26, 2018; Accepted: December 06, 2018; Published: December 10, 2018 
So far, $\mathrm{Na}_{\mathrm{v}} 1.1$ to $\mathrm{Na}_{\mathrm{v}} 1.9$, nine sodium homologous structures have been shown [30]. Among these Navs, mutations in the genes encoding $\mathrm{Na}_{\mathrm{v}} 1.1,1.2$, and 1.6 are highly associated with epilepsy: mutations of SCN2A (encoding $\mathrm{Na}_{\mathrm{v}} 1.2$ ) [31-33] and SCN8A (encoding $\mathrm{Na}_{\mathrm{v}} 1.6$ ) $[34,35]$ are the major causes of genetic epilepsy, the heterozygous loss of function mutation of SCN1A (encoding $\mathrm{Na}_{\mathrm{V}} 1.1$ ) is associated with Dravet syndrome spectrum disorders [36,37], but the connection between $\mathrm{Na}_{\mathrm{v}} 1.3$ and epilepsy is unclear. These toxins and drugs which can modify sodium channel activity have been widely used as tools to study physiological and/or pathological synaptic mechanisms including seizures occur, and at least six sites of toxin binding have been identified [38]. Herein, we further summarized the bidirectional mechanism of scorpion's toxins in convulsant and anticonvulsant as well as the roles of $\mathrm{Na}_{\mathrm{v}}$ mutations in the scorpion toxins effects.

\section{The convulsant effects of scorpion's toxins}

Venomous animals are spread throughout the globe, most species of these animals use their venom for predation or defense, especially concerning scorpion's species [39]. Scorpions are a rather depauperate group within the class Arachnida with approximately 2200 known species up to the present [40]. The scorpion poisoning syndrome is a public health problem tropical region of the world, around 8000 scorpion envenomation accidents are reported every year in Brazil [41], and 14,569 cases were notified in the USA in 2001 [42]. Concerning the capacity of scorpion venom to induce convulsion and the highest risk of epilepsy in the neonatal period, severe intoxication in children with the presence of seizures were reported [43-45], which even secondary to an extensive destructive brain lesion [46]. Recent study suggesting that these deleterious effects induced by scorpion toxins may be a consequence of neuronal damage, also could be due to the results of seizures interfere with developmental processes of immature brain [47]. Moreover, that deleterious effects on the brain play a major role on the lethality induced by scorpion envenoming [48]. Furthermore, Nencioni ALA, et al. [49] reviewed the main effects caused by scorpion venoms, including myocardial damage, cardiac arrhythmias, pulmonary edema and shock-are mainly due to the release of mediators from the autonomic nervous system, also the central nervous system and inflammatory response participated in the process.

So far, sorts of polypeptide scorpion toxins with multipharmacological effects have been purified, which part of these polypeptides have been performed in the rodent studies. Scorpion venom is formed by mucopolysaccharides, hyaluronidase, phospholipase, serotonin, histamine, and protease inhibitors. The clinical manifestations of scorpion venom intoxication exclusively result from the action of $\alpha$ - and $\beta$-toxins [15-17]. The $\alpha$-toxin is present in the venom of Androctonus australis Hector, Androctonus mauretanicu mauretanicus, Buthus eupeus, Buthus occitanus tunetanus, Leiurus quinquestriatus, and $\mathrm{T}$ serrulatus, whereas the $\beta$-toxin can be found in the venom of Centruroides sculpturatus, Centruroides suffusus suffusus, and T serrulatus.

Alpha-type scorpion toxin (TsTX) are peptides of 60-76 amino acid residues in length and tightly bound by four disulfide bridges, animal experiments have shown that these toxins modified the gating mechanism of the $\mathrm{Na}^{+}$-channel function affecting either the inactivation (-toxins) or the activation (-toxins) kinetics of the channels suggesting TsTx is $\mathrm{Na}^{+}$channel specific scorpion toxin of the a type $[38,50]$. TsTX causes incremental overall internal concentrations of sodium and calcium ion, increases channel depolarization time and consequently induces excessive neurotransmitters release such as glutamate in a dose dependent manner. The earliest study of related TsTX, Carvalho FF, et al. intrahippocampal administration of TS-8F toxin, a neuropeptide isolated from Tityus serrulatus scorpion venom, which caused neuronal damage in CA1 and CA2 pyramidal cells and granular cells of the dentate gyrus, induced high-frequency and highvoltage spikes that evolved to seizure activity in the hippocampus and cortex, and resulted in epileptic seizure behavior, suggested the TsTx could lead to changes of neuronal excitability affecting the susceptibility of the central nervous system to convulsions induced by various agents $[15,50]$.

Compared with TsTX, beta-type scorpion toxin (TiTX-gamma) caused little increase of internal sodium and calcium ion concentrations at low doses while evoked a significant increased release of glutamate [51]. Actually, one of the earliest studies found tityustoxin, an active venom component of the Brazilian yellow scorpion Tityus serrulatus, induced specific release of the glutamate, GABA and aspartate neurotransmitter in the synaptosomes of rats superfused sensori-motor cortex due to a depolarising action [52,53]. Also, AF Bicalho found tityustoxin which binds to sodium channel toxin site 3 , have an effect in the increase of glutamate release, $\mathrm{Na}^{+}$influx, $\left[\mathrm{Ca}^{2+}\right] \mathrm{i}$, depolarization and exocytosis at steady state in the rat cerebrocortical isolated nerve endings [54]. These provides an interesting perspective concerning modulation of neurotransmitter release via pharmacological manipulation of $\mathrm{Na}^{+}-$ channel properties, that may lead to a better comprehension of its physiological and pathological roles.

\section{The anticonvulsant effects of scorpion's toxins}

Epilepsy treatment remains challenging in the clinic, and many treatments for epilepsy are still in the exploration stage. Scorpion has been the foremost choice for epileptic treatment as a traditional Chinese medicine [9], exhibiting strong anti-epileptic effects, and the anti-epileptic peptide isolated from the scorpion is more potent [55]. Earlier study that Zhou XH isolated and purified an anti-epilepsy peptide (AEP) from venom of the scorpion Buthus martensii Karsch, showing strongly inhibited epilepsy induced by coriaria lactone and cephaloridine [56]. Later research that Miguel Corona, et al. isolated a novel toxin from the venom of the scorpion Centruroides limpidus limpidus Karsch, named Cll9, which immediately induced sleep when i.c.v. injected in the rat, suggesting a neurodepressant effect and the inhibiting effect of $\mathrm{Na}^{+}$permeability in (cultured) rat peripheral ganglia further supports its neurodepressant actions. However, this peptide did not affect other $\mathrm{Na}^{+}$channels such as those from cerebellum granular cells in culture or the rSkM1 Na+ channels expressed in HEK293 [57].

Buthus martensii Karsch $(\mathrm{BmK})$ is a widely distributed scorpion species in Asia, which has been used to treat epilepsy for a long time. Even the scorpion components remain difficult to determine and its anti-epileptic mechanisms remains poorly understood, it has been speculated that the inhibition of hippocampal astrocyte activity are associated with its anti-epileptic effects [58]. Yi Liang, et al. discovered that the ethanol extracts of scorpion show anti-epileptic effect through decreasing hippocampal glial fibrillary acidic protein expression in a rat model of lithium chloride-pilocarpine induced epilepsy [58]. Moreover, scorpion extract plays a neuroprotective role and inhibits neuronal apoptosis following seizure, prevents glial cell scar formation in epileptic rats, and downregulate transcription factors associated with GFAP gene expression [59-63].

Up to now, several neurotoxins, BmK M1, M4, M8 (mammalian specific) and BmK IT and IT2 (insect specific) have been identified. All the cDNAs of BmK M1, BmK M9 [14] and BmK IT have been cloned, 
while the genomic structures of BmK P01, P03 and P05, BmKTX, BmTX1 and TX2, and Bm-12 have also been elucidated [64]. As far as can be determined, the $\alpha$-toxins bind to receptor site 3 of voltagegated $\mathrm{Na}^{+}$channels of vertebrates when the membranes are polarized. $\mathrm{BmK} \mathrm{I}$, an a-like neurotoxic polypepytide, has been shown to have potent nociceptive actions and to prevent epileptic seizures [65-69]. The $\beta$-toxins bind to receptor site 4 of vertebrate $\mathrm{Na}^{+}$channels causing the opening of $\mathrm{Na}^{+}$channels at more negative potentials. BmK IT2, $\mathrm{BmK}$ AS, and BmK AS-1 have been identified as $\beta$-type neurotoxins [70] and has been shown to inhibit peak tetrodotoxin sensitive (TTX-S) and tetrodotoxin-resistant (TTX-R) sodium currents, while only BmK IT2 has been detected as an effective anticonvulsant in animal seizure models by modulating sodium channels [71].

\section{The different roles of $\mathrm{Na}_{v} \mathrm{~s}$ in epilepsy}

$\mathrm{Na}_{\mathrm{v}} \mathrm{s}$ mediate the generation and propagation of electrical signals (AP) in excitable tissues such as brain, spinal cord and peripheral nerve, and muscle [72-74]. The $\alpha$ and $\beta$ subunits form the $\mathrm{Na}_{\mathrm{v}}$ s structure, and that $\alpha$ subunits consist of four domains (I-IV), each with six transmembrane segments (S1-S6,S1-S4 forming the voltage sensor; S5S6 contributing to the central ion-conducting pore) [72]. In mammals, nine a subunits ( $\left.\mathrm{Na}_{\mathrm{v}} 1.1-1.9\right)$ have been identified which are encoded by the genes SCN1A-5A and SCN8A-11A) [75]. At present the gene (SCN1A-5A and SCN8A-11A) mutation of sodium channels ( Na 1.1 1.9, except $\mathrm{Na}_{\mathrm{v}} 1.3$ ) is a significant cause of abnormal excitability underlying human disease including epilepsy (especially with $\mathrm{Na}_{\mathrm{v}} 1.1,1.2$ and1.6), periodic paralysis, cardiac arrhythmia, and pain syndromes.

\section{SCN1A}

SCN1A is recognized as the most important epilepsy gene discovered to date. It encodes the alpha 1 subunit of the voltage gated sodium channel. Mutations in SCN1A have been reported in patients with different types ofepilepsy, including generalized epilepsy with febrile seizures plus, severe myoclonic epilepsy in infancy, malignant migrating partial seizures in infancy [76]. With Computational analysis of single nucleotide polymorphisms in SCN1A gene of epilepsy, which implicates sodium voltage gated channel function play a key role in epilepsy, the most commonly mutated gene in epilepsy being SCN1A. SCN1A alleles cause protein truncation either by nonsense or frameshift mutation, and a large proportion of missense mutations studied in vitro confer a loss-of-function phenotype to the channel protein [77]. $\mathrm{Na}_{\mathrm{v}} 1.1$, managed by SCN1A, was clustered predominantly at the axon initial segments of parvalbumin-positive (PV) interneurons and involved in sustained high-frequency firing of neocortical fast-spiking interneurons. For knock-in mouse line with a loss-offunction nonsense mutation in the SCN1A gene, both homozygous and heterozygous knock-in mice developed epileptic seizures within the first postnatal month. In heterozygous knock-in mice, trains of evoked action potentials in these fast-spiking, inhibitory cells exhibited pronounced spike amplitude decrement late in the burst [78].

\section{SCN2A}

In adult cerebral cortex of wild-type mice, most $\mathrm{Na}_{\mathrm{v}} 1.2$ is expressed in excitatory neurons with a steady increase and redistribution from proximal (i.e., axon initial segments) to distal axons. Mutations in the SCN2A gene encoding a voltage-gated sodium channel $\mathrm{Na}_{\mathrm{v}} 1.2$ are associated with epilepsies, intellectual disability, and autism [79]. SCN2A mutation of patients cause atypical generalized epilepsy with febrile seizures plus [80]. SCN2A gain-of-function (increased or accelerated, but not toxic) has been recognized as a cause of early infantile-onset severe epileptic encephalopathies such as ohtahara syndrome, whereas loss-of-function SCN2A mutations underlie ASD or intellectual disability with later-onset mild epilepsy or without epilepsy $[81,82]$. Focal epilepsy phenotype is caused by transgenic expression of an engineered $\mathrm{Na}_{\mathrm{v}} 1.2$ mutation displaying enhanced persistent sodium current in Scn2aQ54 mouse [77,78]. It has been reported that the $\alpha$-like scorpion toxin BmK I can enhance membrane excitability via persistent sodium current by preventing slow inactivation and deactivation of $\mathrm{rNa}_{\mathrm{v}} 1.2 \mathrm{a}$ expressed and induce the $\mathrm{I}_{\mathrm{NaP}^{p}}$ which may be involved in the BmK I-induced epilepsy.

\section{SCN8A}

SCN8A encodes the voltage-gated sodium channel $\mathrm{Na}_{\mathrm{v}} 1.6$, and SCN8A-related epilepsies are associated with developmental and epileptic encephalopathies (DEE) including West Syndrome and Lennox-Gastaut Syndrome, as well as benign familial infantile epilepsy (BFIS) and patients with intellectual disability (ID) without epilepsy $[83,84]$. The SCN8A-related DEEs are severe epilepsies, often with refractory seizures, severe cognitive impairment and features such as cognitive visual impairment and spontaneous bone fractures [85]. Alleles that reduce the activity of $S c n 8 a$ are known to increase resistance to acute seizures, reducing seizure severity and improving survival of Scn1a epileptic mutant mice [86-88]. However, reduced Scn8a activity also leads to non-convulsive absence epilepsy in mice [89] and humans [90]. $\mathrm{Na}_{v} 1.6$ is the principal sodium channel implicated in the generation of resurgent current in cerebellar Purkinje and dorsal root ganglia neurons [90], and spontaneous mutations of $\mathrm{Na}_{\mathrm{v}} 1.6$ in the mouse result in neurological disorders including tremor, dystonia, ataxic gait, paralysis, and juvenile lethality $[91,92]$. The $\beta$-toxins purified from scorpion venoms of the Centruroidesspecies affect several voltage-gated sodium channels (VGSCs), which more affected resulted to be $\mathrm{Na}_{\mathrm{v}} 1.6>$ $1.1>1.2$ and induced resurgent current also in isoforms different from $\mathrm{Na}_{\mathrm{v}} 1.6$, suggested that the scorpion toxins play Antiepileptic effects with $\mathrm{Na}_{\mathrm{v}} 1.1, \mathrm{Na}_{\mathrm{v}} 1.2$, play the opposite role with $\mathrm{Na}_{\mathrm{v}} 1.6$ [93]. Moreover, CssII is another $\beta$-scorpion peptide that modifies preferentially sodium currents of the voltage-dependent $\mathrm{Na}^{+}$channel $\left(\mathrm{Na}_{\mathrm{v}} 1.6\right)$ sub-type by the amidated C-terminal of the CssII toward its interaction to the $\mathrm{Na}_{\mathrm{v}} 1.6$ receptor [94].

\section{Conclusion}

Scorpion venoms have been used to treat epilepsy, while scorpion toxins also induce epileptic seizures. $\mathrm{Na}_{\mathrm{v}} \mathrm{s}$ are composed of a poreforming $\alpha$ and auxiliary $\beta$ subunits, and scorpion venom are classified into $\alpha$ and $\beta$ which both can active on $\mathrm{Na}_{\mathrm{v}} 1.1,1.2$ and $1.6\left(\mathrm{Na}_{\mathrm{v}} 1.6>\right.$ $1.1>1.2)$, which may further participant in the pathogenesis or treat mechanism of epilepsy. Hence, further study should be performed to detect the bidirectional effects of scorpion venoms to the pathogenetic mechanism and therapeutic target of epilepsy.

\section{Conflict of interest and statement}

The research was conducted in the absence of any commercial or financial relationships that could be misconstrued as a potential conflict of interest. We confirm that all authors contributed to this manuscript and have approved the final article.

\section{References}

1. Behr C, Goltzene MA, Kosmalski G, Hirsch E, Ryvlin P (2016) Epidemiology of epilepsy. Rev Neurol 172: 27-36.

2. Hernan AE, Holmes GL (2016) Antiepileptic drug treatment strategies in neonata epilepsy. Prog Brain Res 226: 179-193. [Crossref] 
3. Hauser WA, Annegers JF, Kurland LT (1993) Incidence of epilepsy and unprovoked seizures in Rochester, Minnesota: 1935-1984. Epilepsia 34: 453-468. [Crossref]

4. Aneja S, Sharma S (2013) Newer anti-epileptic drugs. Indian Pediatr 50: 1033-1040. [Crossref]

5. Zhao R, Weng CC, Feng Q, Chen L, Zhang XY, et al. (2011) Anticonvulsant activity of BmK AS, a sodium channel site 4-specific modulator. Epilepsy Behav 20: 267-276. [Crossref]

6. Mula M (2016) Third generation antiepileptic drug monotherapies in adults with epilepsy. Expert Rev Neurother 16: 1087-1092. [Crossref]

7. de O Beleboni R, Pizzo AB, Fontana AC, de O G Carolino R, Coutinho-Netto J, et al (2004) Spider and wasp neurotoxins: pharmacological and biochemical aspects. Eur $J$ Pharmacol 493: 01-17. [Crossref]

8. Sandoval MR, Lebrun I (2002) TsTx toxin isolated from Tityus serrulatus scorpion venom induces spontaneous recurrent seizures and mossy fiber sprouting. Epilepsia 44: 904-911. [Crossref]

9. Wang Y, Zhang XY, Li S, Zhang J, Zhao J, et al. (2007) Inhibitory effects of scorpion venom heat resistant protein on the excitability of acutely isolated rat hippocampal neurons. Sheng Li Xue Bao 59: 87-93. [Crossref]

10. Hodgkin AL, Huxley AF (1952) A quantitative description of membrane current and its application to conduction and excitation in nerve. J Physiol 117: 500-544. [Crossref]

11. Chanda B, Bezanilla F (2002) Tracking voltage-dependent conformational changes in skeletal muscle sodium channel during activation. J Gen Physiol 120: 629-645. [Crossref]

12. Capes DL, Goldschen-Ohm MP, Arcisio-Miranda M, Bezanilla F, Chanda B (2013) Domain IV voltage-sensor movement is both sufficient and rate limiting for fast inactivation in sodium channels. J Gen Physiol 142: 101-112. [Crossref]

13. Goldschen-Ohm MP, Capes DL, Oelstrom KM, Chanda B (2013) Multiple pore conformations driven by asynchronous movements of voltage sensors in a eukaryotic sodium channel. Nat Commun 4: 1350. [Crossref]

14. Lacroix JJ, Campos FV, Frezza L, Bezanilla F (2013) Molecular bases for the asynchronous activation of sodium and potassium channels required for nerve impulse generation. Neuron 79: 651-657. [Crossref]

15. Possani LD, Becerril B, Delepierre M, Tytgat J (1999) Scorpion toxins specific for $\mathrm{Na}$ -channels. Eur J Biochem 264: 287-300. [Crossref]

16. Dang B, Kubota T, Mandal K, Correa AM, Bezanilla F, et al. (2016) Elucidation of the Covalent and Tertiary Structures of Biologically Active Ts3 Toxin. Angew Chem Int Ed Engl 55: 8639-8642. [Crossref]

17. Cestele S, Catterall WA (2000) Molecular mechanisms of neurotoxin action on voltagegated sodium channels. Biochimie 82: 883-892. [Crossref]

18. Rogers JC, Qu Y, Tanada TN, Scheuer T, Catterall WA (1996) Molecular determinants of high affinity binding of alpha-scorpion toxin and sea anemone toxin in the S3-S4 extracellular loop in domain IV of the $\mathrm{Na}^{+}$channel alpha subunit. Biol Chem 271: 15950-15962. [Crossref]

19. Benzinger GR, Kyle JW, Blumenthal KM, Hanck DA (1998) A specific interaction between the cardiac sodium channel and site-3 toxin Anthopleurin B. J Biol Chem 273: 80 .

20. Catterall WA (1977) Membrane potential-dependent binding of scorpion toxin to the action potential $\mathrm{Na}^{+}$ionophore. Studies with a toxin derivative prepared by lactoperoxidase-catalyzed iodination. J Biol Chem 252: 8660-8668. [Crossref]

21. Couraud F, Rochat H, Lissitzky S (1978) Binding of scorpion and sea anemone neurotoxins to a common site related to the action potential $\mathrm{Na}^{+}$ionophore in neuroblastoma cells. Biochem Biophys Res Commun 83: 1525-1530. [Crossref]

22. Kirsch GE, Skattebøl A, Possani LD, Brown AM (1989) Modification of Na channel gating by an alpha scorpion toxin from Tityus serrulatus. J Gen Physiol 93: 67-83. [Crossref]

23. Campos FV, Coronas FI, Beirão PS (2004) Voltage-dependent displacement of the scorpion toxin Ts3 from sodium channels and its implication on the control of inactivation. Br J Pharmacol 142: 1115-1122. [Crossref]

24. Campos FV, Chanda B, Beirão PS, Bezanilla F (2008) Alpha-scorpion toxin impairs a conformational change that leads to fast inactivation of muscle sodium channels. $J$ Gen Physiol 132: 251-263. [Crossref]

25. Campos FV, Chanda B, Beirão PS, Bezanilla F (2007) beta-Scorpion toxin modifies gating transitions in all four voltage sensors of the sodium channel. J Gen Physiol 130: 257-268. [Crossref]
26. Cestèle S, Qu Y, Rogers JC, Rochat H, Scheuer T, et al. (1998) Voltage sensor-trapping: enhanced activation of sodium channels by beta-scorpion toxin bound to the S3-S4 loop in domain II. Neuron 21: 919 - 931. [Crossref]

27. Marcotte P, Chen LQ, Kallen RG, Chahine M (1997) Effects of Tityus serrulatus scorpion toxin gamma on voltage-gated $\mathrm{Na}^{+}$channels. Circ Res 80: 363-369. [Crossref]

28. Zhang JZ, Yarov-Yarovoy V, Scheuer T, Karbat I, Cohen L, et al. (2011) StructureFunction Map of the Receptor Site for $\beta$-Scorpion Toxins in Domain II of Voltage-gated Sodium Channels. J Biol Chem 286: 33641-33651. [Crossref]

29. Zhang JZ, Yarov-Yarovoy V, Scheuer T, Karbat I, Cohen L, et al. (2012) Mapping the Interaction Site for a $\beta$-Scorpion Toxin in the Pore Module of Domain III of Voltagegated $\mathrm{Na}^{+}$Channels. J Biol Chem 287: 30719-30728. [Crossref]

30. Zaman T, Helbig I, Božović IB, DeBrosse SD, Bergqvist AC, et al. (2018) Mutations in SCN3A cause early infantile epileptic encephalopathy. Ann Neurol 83: 703-717. [Crossref]

31. Wolff M, Johannesen KM, Hedrich UBS, Masnada S, Rubboli G, et al. (2017) Genetic and phenotypic heterogeneity suggest therapeutic implications in SCN2A-related disorders. Brain 140: 1316-1336. [Crossref]

32. Kearney JA, Plummer NW, Smith MR, Kapur J, Cummins TR, et al. (2001) A gain-offunction mutation in the sodium channel gene $\operatorname{Sen} 2$ a results in seizures and behavioral abnormalities. Neuroscience 102: 307-317. [Crossref]

33. Sugawara T, Tsurubuchi Y, Agarwala KL, Ito M, Fukuma G, et al. (2001) A missense mutation of the $\mathrm{Na}^{+}$channel alpha II subunit gene $\mathrm{Na}(\mathrm{v}) 1.2$ in a patient with febrile and afebrile seizures causes channel dysfunction. Proc Natl Acad Sci USA 98: 6384-6389. [Crossref]

34. Larsen J, Carvill GL, Gardella E, Kluger G, Schmiedel G, et al. (2015) The phenotypic spectrum of SCN8A encephalopathy. Neurology 84: 480-489. [Crossref]

35. Veeramah KR, O'Brien JE, Meisler MH, Cheng X, Dib-Hajj SD, et al. (2012) De Novo Pathogenic SCN8A Mutation Identified by Whole-Genome Sequencing of a Family Quartet Affected by Infantile Epileptic Encephalopathy and SUDEP. Am J Hum Genet 90: 502-510. [Crossref]

36. Claes L, Del-Favero J, Ceulemans B, Lagae L, Van Broeckhoven C, et al. (2001) De novo mutations in the sodium-channel gene $\mathrm{SCN} 1 \mathrm{~A}$ cause severe myoclonic epilepsy of infancy. Am J Hum Genet 68: 1327-1332. [Crossref]

37. Claes L, Ceulemans B, Audenaert D, Smets K, Löfgren A, et al. (2003) De novo SCN1A mutations are a major cause of severe myoclonic epilepsy of infancy. Hum Mutat 21: 615-621. [Crossref]

38. Cestele S, Catterall WA (2000) Molecular mechanisms of neurotoxin action on voltagegated sodium channels. Biochimie 82: 883-892. [Crossref]

39. Dehghani R, Kamiabi F, Mohammadi M (2018) Scorpionism by Hemiscorpius spp. in Iran: a review. J Venom Anim Toxins Incl Trop Dis 24: 8. [Crossref]

40. Lourenço WR (2018) The evolution and distribution of noxious species of scorpions (Arachnida: Scorpiones) Louren. J Venom Anim Toxins Incl Trop Dis 24: 1.

41. Funasa Md (2001) Manual de Diagnostico por Animais Peconhentos.

42. Bush SP, Gerardo CJ (2003) Scorpion envenomation

43. Amitai Y, Mines Y, Aker M, Goitein K (1985) Scorpion sting in children. A review of 51 cases. Clin Pediatr (Phila) 24: 136-140. [Crossref]

44. Fernández-Bouzas A, Morales-Reséndiz ML, Llamas-Ibarra F, Martínez-López M, Ballesteros-Maresma A (2000) Brain infarcts due to scorpion stings in children: MRI. Neuroradiology 42: 118-120. [Crossref]

45. Osnaya-Romero N, de Jesus Medina-Hernández T, Flores-Hernández SS, León-Roja G (2001) Clinical symptoms observed in children envenomated by scorpion stings, at the children's hospital from the State of Morelos, Mexico. Toxicon 39: 781-785. [Crossref]

46. Bonilha L, Cendes F, Ghizoni E, Vieira RJ, Li LM (2004) Epilepsy due to a destructive brain lesion caused by a scorpion sting. Arch Neurol 61: 1294-1296. [Crossref]

47. Holopainen IE (2008) Seizures in the developing brain: Cellular and molecular mechanisms of neuronal damage, neurogenesis and cellular reorganization. Neurochem Int 52: 935-947. [Crossref]

48. Guidine PA, Moraes-Santos T, Massensini AR, Moraes MF (2008) Carbamazepine protects the CNS of Wistar rats against the central effects of scorpion envenomation. Neurotoxicology 29: 136-142. [Crossref]

49. Nencioni ALA, Neto EB, de Freitas LA, Dorce VAC (2018) Effects of Brazilian scorpion venoms on the central nervous system. J Venom Anim Toxins Incl Trop Dis 24: 3. [Crossref] 
50. Carvalho FF, Nencioni AL, Lebrun I, Sandoval MR, Dorce VA (1998) Behavioral, electroencephalographic, and histopathologic effects of a neuropeptide isolated from Tityus serrulatus scorpion venom in rats. Pharmacol Biochem Behav 60: 7-14. [Crossref]

51. Massensini AR, Moraes-Santos T, Gomez MV, Romano-Silva MA (1998) Alpha- and beta-scorpion toxins evoke glutamate release from rat cortical synaptosomes with different effects on [Na+]i and [Ca2+]i. Neuropharmacology 37: 289-297. [Crossref]

52. Coutinho-Netto J, Abdul-Ghani AS, Norris PJ, Thomas AJ, Bradford HF (1980) The effects of scorpion venom toxin on the release of amino acid neurotransmitters from cerebral cortex in vivo and in vitro. $J$ Neurochem 35 : 558-565. [Crossref]

53. Silva FC, Guidine PA, Machado NL, Xavier CH, de Menezes RC, et al. (2015) The role of dorsomedial hypotalamus ionotropic glutamate receptors in the hypertensive and tachycardic responses evoked by Tityustoxin intracerebroventricular injection. Neurotoxicology 47: 54-61. [Crossref]

54. Bicalho AF, Guatimosim C, Prado MA, Gomez MV, Romano-Silva MA (2002) Investigation of the modulation of glutamate release by sodium channels using neurotoxins. Neuroscience 113: 115-123. [Crossref]

55. Wang CG, He XL, Shao F, Liu W, Ling MH, et al. (2001) Molecular characterization of an anti-epilepsy peptide from the scorpion Buthus martensi Karsch. Eur J Biochem 268: 2480-2485. [Crossref]

56. Zhou XH, Yang D, Zhang JH, Liu CM, Lei KJ (1989) Purification and N-terminal partial sequence of anti-epilepsy peptide from venom of the scorpion Buthus martensii Karsch. Biochem J 257: 509-517. [Crossref]

57. Corona M, Coronas FV, Merino E, Becerril B, Gutiérrez R, et al. (2003) A novel class of peptide found in scorpion venom with neurodepressant effects in peripheral and central nervous system of the rat. Biochim Biophys Acta 1649: 58-67. [Crossref]

58. Liang Y, Sun H, Yu L, He B, Xie Y (2012) Scorpion ethanol extract and valproic acid effects on hippocampal glial fibrillary acidic protein expression in a rat model of chronic-kindling epilepsy induced by lithium chloride-pilocarpine. Neural Regen Res 7: 426-433. [Crossref]

59. Jiang CL, Zhang WQ (2002) Regulation of glial fibrillary acidic protein gene by scorpion venom against epileptic seizures. Zhongguo Ying Yong Sheng Li Xue Za Zhi 18: 406-407. [Crossref]

60. Rogawski MA, Löscher W (2004) The neurobiology of antiepileptic drugs. Nat Rev Neurosci 5: 553-564. [Crossref]

61. Zhao R, Zhang XY, Yang J, Weng CC, Jiang LL, et al. (2008) Anticonvulsant effect of BmK IT2, a sodium channel-specific neurotoxin, in rat models of epilepsy. $\mathrm{Br} J$ Pharmacol 154: 1116-1124. [Crossref]

62. Fattorusso R, Frutos S, Sun X, Sucher NJ, Pellecchia M (2006) Traditional Chinese medicines with caspase-inhibitory activity. Phytomedicine 13: 16-22. [Crossref]

63. Cheng WG, Zhang JP, Wang B (2003) The effects of scorpion venom on GFAP and GABA in entorhinal cortex of epileptic rats induced by kainic acid. Zhongguo Zhongxiyi Jiehe Zazhi 4: 1126-1128.

64. Wang CG, He XL, Shao F, Liu W, Ling MH, et al. (2001) Molecular characterization of an anti-epilepsy peptide from the scorpion Buthus martensi Karsch. Eur J Biochem 268: 2480-2485. [Crossref]

65. Bai ZT, Zhang XY, Ji YH (2003) Fos expression in rat spinal cord induced by peripheral injection of BmK I, an alpha-like scorpion neurotoxin. Toxicol Appl Pharmacol 192: 78-85. [Crossref]

66. Bai ZT, Zhao R, Zhang XY, Chen J, Liu T, et al. (2006) The epileptic seizures induced by BmK I, a modulator of sodium channels. Exp Neurol 197: 167-176. [Crossref]

67. Chen J, Tan ZY, Zhao R, Feng XH, Shi J, et al. (2005) The modulation effects of BmK $\mathrm{I}$, an alpha-like scorpion neurotoxin, on voltage-gated $\mathrm{Na}+$ currents in rat dorsal root ganglion neurons. Neurosci Lett 390: 66-71. [Crossref]

68. Ji YH, Mansuelle P, Terakawa S, Kopeyan C, Yanaihara N, et al. (1996) Two neurotoxins (BMK I and BMK II) from the venom of the scorpion Buthus martensi Karsch: purification, amino acid sequences and assessment of specific activity. Toxicon 34: 987-1001. [Crossref]

69. Zhang XY, Zhang JW, Chen B, Bai ZT, Shen J, et al. (2002) Dynamic determination and possible mechanism of amino acid transmitter release from rat spinal dorsal horn induced by the venom and a neurotoxin (BmK I) of scorpion Buthus martensi Karsch. Brain Res Bull 58: 27-31. [Crossref]

70. Ji YH, Li YJ, Zhang JW, Song BL, Yamaki T, et al. (1999) Covalent structures of BmK AS and BmK AS-1, two novel bioactive polypeptides purified from Chinese scorpion Buthus martensi Karsch. Toxicon 37: 519-536. [Crossref]
71. Zhao R, Zhang XY, Yang J, Weng CC, Jiang LL, et al. (2008) Anticonvulsant effect of BmK IT2, a sodium channel-specific neurotoxin, in rat models of epilepsy. $B r J$ Pharmacol 154: 1116-1124. [Crossref]

72. Catterall WA (2000) From ionic currents to molecular mechanisms: the structure and function of voltage-gated sodium channels. Neuron 26: 13-25. [Crossref]

73. Catterall WA (2012) Voltage-gated sodium channels at 60: structure, function and pathophysiology. J Physiol 590: 2577-2589. [Crossref]

74. O’Malley HA, Isom LL (2015) Sodium Channel $\beta$ Subunits: Emerging Targets in Channelopathies. Annu Rev Physiol 77: 481-504. [Crossref]

75. Catterall WA, Goldin AL, Waxman SG, International Union of Pharmacology (2003) International Union of Pharmacology. XXXIX. Compendium of Voltage-Gated Ion Channels: Sodium Channels. Pharmacol Rev 55 :575-578. [Crossref]

76. Schutte SS, Schutte RJ, Barragan EV, O'Dowd DK (2016) Model systems for studying cellular mechanisms of SCN1A-related epilepsy. J Neurophysiol 115: 1755-1766. [Crossref]

77. Morimoto M, Mazaki E, Nishimura A, Chiyonobu T, Sawai Y, et al. (2006) SCN1A mutation mosaicism in a family with severe myoclonic epilepsy in infancy. Epilepsia 47: 1732-1736. [Crossref]

78. Ogiwara I, Miyamoto H, Morita N, Atapour N, Mazaki E, et al. (2007) Nav1.1 localizes to axons of parvalbumin-positive inhibitory interneurons: a circuit basis for epileptic seizures in mice carrying an Scn1 a gene mutation. J Neurosci 27: 5903-5914. [Crossref]

79. Ikuo O, Hiroyuki M, Tetsuya T, Yamagata T, Nakayama T, et al. (2018) Nav1.2 haplodeficiency in excitatory neurons causes absence-like seizures in mice. Commun Biol 96.

80. Sugawara T, Tsurubuchi Y, Agarwala KL, Ito M, Fukuma G, et al. (2001) A missense mutation of the $\mathrm{Na}+$ channel alpha II subunit gene Nav1.2 in a patient with febrile and afebrile seizures causes channel dysfunction. Proc Natl Acad Sci U S A 98: 6384-6389. [Crossref]

81. Ben-Shalom R, Keeshen CM, Berrios KN, An JY, Sanders SJ, et al. (2017) Opposing effects on Nav1.2 function underlie differences between SCN2Avariants observed in individuals with autism spectrum disorder or infantile seizures. Biol Psychiatry 82: 224-232. [Crossref]

82. Wolff M, Johannesen KM, Hedrich UBS, Masnada S, Rubboli G, et al. (2017) Genetic and phenotypic heterogeneity suggest therapeutic implications in SCN2A-related disorders. Brain 140: 1316-1336. [Crossref]

83. Blanchard MG, Willemsen MH, Walker JB, Dib-Hajj SD, Waxman SG, et al. (2015) De novo gain-of-function and loss-of-function mutations of SCN8A in patients with intellectual disabilities and epilepsy. J Med Genet 52: 330-337. [Crossref]

84. Gardella E, Becker F, Møller RS, Schubert J, Lemke JR, et al. (2016) Benign infantile seizures and paroxysmal dyskinesia caused by an SCN8A mutation. Ann Neurol 79: 428-436. [Crossref]

85. Johannesen KM, Gardella E, Scheffer I, Howell K, Smith DM, et al. (2018) Early mortality in SCN8A-related epilepsies. Epilepsy Res 143: 79-81. [Crossref]

86. Hawkins NA, Martin MS, Frankel WN, Kearney JA, Escayg A (2011) Neurona voltage-gated ion channels are genetic modifiers of generalized epilepsy with febrile seizures plus. Neurobiol Dis 41: 655-660. [Crossref]

87. Makinson CD, Tanaka BS, Lamar T, Goldin AL, Escayg A (2014) Role of the hippocampus in Nav1.6 (Scn8a) mediated seizure resistance. Neurobiol Dis 68: 16-25. [Crossref]

88. Martin MS, Tang B, Papale LA, Yu FH, Catterall WA, et al. (2007) The voltage-gated sodium channel $\mathrm{Scn} 8 \mathrm{a}$ is a genetic modifier of severe myoclonic epilepsy of infancy. Hum Mol Genet 16: 2892-2899. [Crossref]

89. Papale LA, Beyer B, Jones JM, Sharkey LM, Tufik S, et al. (2009) Heterozygous mutations of the voltage-gated sodium channel SCN8A are associated with spike-wave discharges and absence epilepsy in mice. Hum Mol Genet 18: 1633-1641. [Crossref]

90. Berghuis B, de Kovel CG, van Iterson L, Lamberts RJ, Sander JW, et al. (2015) Complex SCN8A DNA-abnormalities in an individual with therapy resistant absence epilepsy. Epilepsy Res 115: 141-144. [Crossref]

91. Cummins TR, Dib-Hajj SD, Herzog RI, Waxman SG (2005) Nav1.6 channels generate resurgent sodium currents in spinal sensory neurons. FEBS Lett 579: 2166-2170. [Crossref]

92. Meisler MH, Plummer NW, Burgess DL, Buchner DA, Sprunger LK (2004) Allelic mutations of the sodium channel SCN8A reveal multiple cellular and physiological functions. Genetica 122: 37-45. [Crossref] 
93. Schiavon E, Pedraza-Escalona M, Gurrola GB, Olamendi-Portugal T, Corzo G, et al (2012) Negative-shift activation, current reduction and resurgent currents induced by $\beta$-toxins from Centruroides scorpions in sodium channels. Toxicon 59: 283-293. [Crossref]
94. Estrada G, Restano-Cassulini R, Ortiz E, Possani LD, Corzo G (2011) Addition of positive charges at the C-terminal peptide region of CssII, a mammalian scorpion peptide toxin, improves its affinity for sodium channels Nav1.6. Peptides 32: 75-79. [Crossref]

Copyright: (C2018 Wang Y. This is an open-access article distributed under the terms of the Creative Commons Attribution License, which permits unrestricted use, distribution, and reproduction in any medium, provided the original author and source are credited. 